\title{
Preventive strategies in oral health promotion
}

\author{
Prevenção na promoção de saúde bucal
}

Andréa Gonçalves An tonio 1

Lucianne Cople Maia 1

Roberto Braga de Carvalho Vianna 1

Luís Eduardo Lavigne Paranhos Quintanilha 2

\footnotetext{
${ }^{1}$ Faculdade de O dontologia, UFRJ. Av. Brigadei ro Trom pows ky $\mathrm{s} / \mathrm{n}$, Gidade Un iversitária, 21941-590, Rio de Janei roRJ. agan tonio@ig.com.br 2 Un iversid ade Federal Fluminense.
}

\begin{abstract}
The biofilm control is a considerable factor in the prevention and treatment of oral diseases as caries and periodontal disease. However, according to the literature, the collective programs show frustrating re sults at long-term due to difficulty to change the behavior of the participant individuals. Therefore, taking into consideration the model of the dental practice in Brazil, where the population has an oral health needfulness, the purpose of this study is to introduce different strategies that allow the accomplishment of collective programs, so that they succe ed in the promotion of the oral health either in individual or collective level.
\end{abstract}

Key words Preventive strategies, Motivation, Health promotion
Resumo O controle do bi ofilme dental constitui um importante fator na prevenção e tratamen to de doenças bucais como a cárie e a doença periodontal. No entanto, a literatu ra nos revela que os programas coletivos apresentam resultados frustrantes a longo prazo devido à dificuldade em se mudar definitivamente o comportamen to dos indivíduos participantes. Assim, levando-se em consideração o modelo da prática odontológica encontrada no Brasil, onde a população tem carência de saúde bucal, o propósitodeste trabalho é apresentar, sob uma perspectiva preven tiva, diferentes estratégias, que viabilizen a realização de programas, a fim de que os mesmos possam ter êxi to na promoção da saúde bucal tanto em nível individual como coletivo.

Palavras-chave Estratégias preventivas, motivação, promoção de saúde 


\section{Introduction}

The etiological role of the bacterial plaque or dental biofilm in periodontal and caries diseases was sugge sted for the first time at the end of the 19th century by a dentist called Miller (1890, apud Akikain en\& Alaluusua, 1993). The dental bi ofilm is defined as a soft bacterial deposit, non-mineralized, which adheres to the solid surf aces in the oral cavity wh en these are not adequately hygienised (Dawes \& Jenkins, 1962; Kelstrup \& Theilade, 1974).

Since oral diseases such as caries and periodontal disease are infecti ons caused by indigenous oral flora, it is on ly wh en the nu mbers of these microorganisms increase, and the resultant irritation exceeds the host's defense threshold that the disease manifests itself (Slots, 1979; Hamada \& Slade, 1980). However this probl em can be easily con trolled through the reduction of the amount of biofilm or plaque on dental surfaces (Zickert et al., 1982; Rayner, 1992; Sgan-Cohen \& Vered, 2003), a solution proposed in many oral health programs which aim at reducing or eliminating the bacterial plaque. Despite this approach, the majority of these programs fail to achieve their aims owing to the lack of due attention to pre-requisites essential to any prevention program, as it is the case of the em phasis on the patient-professional relationship in its educational aspect (Sheiham, 1983).

Wh en ever education is mentioned, it refers to people's developm ent from birth and througho ut their lives, in the process of both searching for and ach $i$ eving the fulfill $m$ ent of th eir needs. At the same time this development occurs within social relationships, it is determined by them, in a diffuse as well as organized way. The in terven tional acti ons that occur in this process can be translated as both domination and liberati on instruments. From this point of vi ew, education and health are social practices, and a re inserted in a wider political process which interferes in social dynamics (Teixei ra \& Valença, 1998).

Within this context, it is absolutely relevant to consider that several social and educational va riables influ en ce human behaviour con cerning oral hygiene, and that they can ef fect definitive changes in human attitudes and habits. One the most important among these variables is socialization, that is, the process through which informal knowledge, values, attitudes and ro utine practices are transmitted to the in- divi dual by means of social interacti on (WHO, 1979). A case in point is the attitu de of child ren who copy their parents' and teachers' toothbrushing habits (Sheiham, 1983). By the time they re ach adolescence, brushing has become an integral part of their hygiene and self-care practi ces (Hod ge et al., 1982).

Literature tells us that the less life risk an individual perceives a given disease might bring him the less his involvement is with the procedu res which might prevent it (Wilson, 1987; Ong, 1991). In order to revert this situation, it is imperative to re-think and re-organize health education, so that it may then provi de awareness, knowled ge and devel opment of practical skills to ach i eve oral health.

In this way a favorable result of programs for oral health promotion - emphasizing preven ti on - can be improved thro ugh the combination of biofilm reduction measures and health education (Sheiham, 1983). In the same line of reasoning, the presentation of different strategies can be considered a fundamental man euver for quality of life improvement in a given population - provided these strategies originate in a prevention approach and allow the implementation of su ccessful programs for oral health promotion and balance both at indivi dual and collective levels.

\section{Program planning}

Over thirty years ago, Hein fetz et al. (1973) asserted the necessity of evaluating biofilm control programs, con si dering in particular the detailing of the results obtained, in order to define a viable program by outlining its operational aspects throughout its conduction. That is, they judged the examination of results and of both previous and pres ent experiments in a biofilm control program to be of negligible importance, and con sidered the available human and financial resources, as well as the accessible equipment and materials for its implementation, as the adequate means to ascertain its validity.

It can thus be unders tood that the elaborati on of an adequate prevention program for a given disease, with all its biop sych o s ocial complexity, demands the adoption of some pre-requisites such as the assessment of the population the program is to aim at, the indivi dual risk of developing the diseases and the benefits expected by both health professionals and individuals that are to participate in it (Lang et al., 1998). 


\section{Identification of the target population ben efited by the program}

A fundamental question in the planning of health programs is to wh om direct the preventive measures (Heifetz et al., 1973). Owing to the possibility of habit modulation in young individuals, as opposed to changes in established practices in adults (Albandar et al., 1995), the great majority of the programs reported in literatu re involves dildren, distributed in different age groups (Axelss on \& Lindhe, 1974; Carvalho et al., 1991; Albandar et al., 1994; Julien, 1994).

Udin, in 1999, con si dered the implementation of preventive programs in first infancy to be inherent to the process of healthyhabits acquisiti on at the earliest possible date, as long as it is ad a pted to indivi dual needs as the child ren mature.

Concerning pre-school programs, certain authors recom $m$ end parent participation (Ca rvalho et al., 1992; Axelssonet al., 1993). Rayner (1992) observed that parent education is directly related to the improvement in oral hygi ene and gin givitis in child ren.

Pregnant women's training to avoid the transmission of contagion by cariogenic mic roorganisms and harmful eating habits have also been a main focus in some programs (Axel ss on et al., 1993; Min kovitz et al., 2002; Za nata et al., 2003). These wom en are very receptive to new practices, especially when they involve the well - being of th eir futu re babi es.

However, there are caries prevention studies which concern only the permanent dentition of child ren and ado le s cents (Carvalho et al., 1989; 1992; S chwarz et al., 1998). Elkstrand et al. (2000) reported that the implementation of a children's program is only viable when they enter school, from the age of three onwards.

It should also be emphasized that the first step for su ccess in a program is the identificati on of e ach indivi dual's edu cational needs, for it is on ly through knowledge of the individual ch a racteris tics of human behaviour that it will be possible to outline an action plan for the benefit of the whole community (Wentz, 1972). Mastrantonio \& Garcia (2002) thus suggest that, for the elaboration of preventive educati onal programs, questionnaires and interviews should be applied before its implem en tation in order to ascertain the level of odontological knowledge of the participants and to ad apt the program to their real educational needs.
Furthermore, it is impossible to implement a program without being aw a re of the ex pect ations of the population, which will gather its benefits. Health promotion and maintenance depend on the joint performance of acting professionals and target population (Kriger $e t$ al., 2003).

\section{Risk stra tegy}

Considering the natural history of diseases, the assessment of their pre-pathogenic stage is of fundamental importance to the implementation of a health program. Thus, to identify the factors rel a ted to the risk of devel oping certain diseases - such as, for example, caries and periodontal disease - becomes a great challenge to be faced by any oral health team involved with the implementati on of collective programs. Numerous caries and periodontal disease hazards have been suggested, both at in divi dual and coll ective level s, sinceindivi duals with high disease levels have specific characteristics andhabits, and show a positiveassociation bet ween the progress of these diseases and that which determined their occurrence (Tinanoff, 1995). That is why the meticulous examinati on of risk factors to iden tify vulnerable individuals is considered an essential condition for submitting the population to the preventive measu res planned in the program (Axelssonet al., 1993).

Therefore the identification of these haza rds is the basis for the planning of health-care activities. Su ch planning needs to be based on the most realistic information and data that can possibly be obtained, and they should provide the designers of the program with a true overview including, among other data, the amount of a given problem present in the target population and the intensity with which it to u ches upon the said population (Silveira $e t$ al., 2002).

To arrive at a collective diagnosis, the professional must needs diagnose the individual probl ems and have proper professional qualification in both hazard factors and already established pathological processes, which, if left as they are found, perpetuate the demand for invasive treatments. From the starting point of a situati onal diagnosis obtain ed from epidemiological surveys, collective stra tegies can be devised for the prevention and control of oral diseases. Regarding dental caries and periodontal disease, although the harm caused by 
their unhampered progress may be visible, it is known that their control and prevention can be effected. The intervention aimed at biofilm con trol is one of the most frequ en ty used measu res in health programs (Zi ckert et al., 1982), with usually positive re sults concerning the reducti on of plaque, gin givitis and caries indexes (Marthaler\& Moos, 1983).

In this sense, acting on hazard factors is a reminder of the fact that we are performing an activity that has the promotion of oral health as its prime obj ective. For this goal to be ef fectively re ached, it is necessary to seek the most adequate means of intervention on the population, in order to sensitize and motiva te it for the obtention and maintenance of healthy habits.

It is of the utmost importance in the process that the individuals become aware of their actual oral health condition. A precise diagnosis, jointly made with the patient, is an essential pre-requisite to ascertain his oral needs. Furthermore, it is necessary to detect the patient's unprovided needs, which are presented as more important than his dental problems. A better knowled ge of the individual, in cluding knowledge of his willingness to keep his teeth, enables the health profe s si onal to draw near to this patient's expectations (Buischi \& Axelsson, 1997).

\section{Motivation}

For the pati ent to be encoura ged to change his habits, it is fundamental that, in the first place, he should receive informati on rega rding oral health that would justify this need for change (Ong, 1991), concepts such as etiology, progression, treatment and control of caries and peri odontal diseases (Carvalho et al., 1991; Axels s on et al., 1994).

However, for individuals to learn how to keep healthy it is not en ough to explain in det a il the causes of diseases and how to avoid them, and then demand that the lesson be learned forthwith. It is necessary to foster the will to learn, to awaken the curiosity and interest that induce action, to en cou rage the determination to achieve the target results, to expand internal conditions favora ble to learning (Petry \& Pret to, 2003). Therefore the patient needs to be well motivated to establish satis factory health habits, and, on principle, the program should prefera bly start from the idea that motiva ti on is either to be ready to act or the force that impels towards acti on (Resende, 1986).
Thus, a com pletexamination, the patient's training - taking into consideration his oral health condition - foll owed by a detailed discussion of intervention measu res should precede the stage of oral care instru ction. It is necessary that the individual understands and accepts the reasons for his change of oral habits before the dentist begins oral hygi ene instructi on (Ong, 1991). The den tist is frequ en tly observed to impose his point of view on the patient, thus underestimating this patient's own desired change of behaviour (Weinstein, 1982; Wilson, 1987). That is why, and first of all, the careful hearing and ob s ervati on of the patient's reactions and the discussion of his needs will h elp him actively con tribute to the program in wh i ch he is inserted (Petry \& Pret to, 2003).

The professional's support, through positive reinforcem ent - approving of the pati ent's effort with a minimum of negative criticism seems to favor the indivi dual's active involvement in the program, by means of the self-diagnosis of his condition and odontological needs (Albandar et al., 1994; Axelsson et al., 1994).

Additionally, there is the fact that real interest on the part of the den tist and his care for the patient's well-being gives rise to another positive aspect, that is, the satisfaction this indivi dual feels and the consequ ent involvement he will have with the program (Petry \& Pret to, 2003). To listen to the patient and to discuss with him his complaints and ex pectations provides enough favora ble con ditions to all ow the dentist to implem ent his educational and motiva ti onal stra tegy (Ong, 1991).

It is evident that the motivation factor is the propulsive force for the obtention of positive results in the task of the patient's health education, individually or collectively. The whole working team needs to be ready for action. The professional needs to know his patient as a whole - biologically, socially and emotionally - in order to be able to motivate him to acquire new habits. Furthermore, the professional needs to be sensitive, to enjoy what he does and to have a sound techno-scien tific knowled ge (Cabral, 1998).

\section{D ental biofilm con trol and health education}

For the mainten a n ce of healthy dental and gingival ti s sues in the oral cavity it is important to 
institute mechanical means for bi ofilm con trol, be it through oral hygiene instruction, professional prophylaxis (Axelsson \& Lindhe, 1974) or instruction associa ted with su pervised bru s hing (Marthaler\& Moos, 1983).

Corroborating with this assertion, Mastrantonio \& Garcia (2002) single out mechanic con trol as being the most recognizablyefficient method for the upkeep of oral health, but, on the other hand, they emphasize that even though they use it, pati ents still present deficient oral hygiene, owing to lack of information, aw a reness and education.

Because of this, educational activities promoting knowledge of the etiology of oral diseases and of means of controlling such pathogenesis consti tute important factors that favorably influen ce the acquisition of a new beh avioral pattern and of hygiene attitudes (Sheiham, 1983).

It is then of capital importance that due value be given to health education, that is, to the transformation process that develops people's critical aw a reness rega rding their health probl ems and encourages the search for collective solutions to eliminate them. Educational practice, thus unders tood, is an integral part of health acti on itself and as su ch should be made to work in an integra ted manner at every system level and in every phase of the organization and development process of health services (Rocha, 1989).

Nevertheless it is important to bring to notice that in order to obtain favorable results in a program it is necessary to instruct the individuals in a positive, non-detrimental way, for no one enjoys being criticized or hearing that his mouth is extrem ely dirty. On the contrary, the patient's real oral condition should be shown him by means of the visualizati on of the existing dental biofilm, which would all ow the establishment of a non-threatening patientprofessional dialogue abo ut the problems deriving from this bacterial accretion (Ong, 1991) and about the benefits accrued through oral self-caremeasures.

In truth, individuals faced with these po sitive attitudes tend to remain involved in the program, as their sense of responsibility for the re sults to be achieved increases (Petry \& Pretto, 2003).

Therefore, instead of a process of persuasion or information transfer, health education becomes a qualification process - both for individuals and groups - to achieve a reality change. In this context, a real commitment of the involved subjects should be seeked, these last including both the population and the health professionals (Roch a, 1989).

\section{Maintenance}

Already in 1977 Sheiham affirmed that programs should be con ti nuous and not limited to a series of short campaigns. Regular re-instru ction and re-motivation are important strategies in the bi ofilm control program, and the interval bet ween activities depends on variables such as susceptibility to the disease, patient dexterity and motivation (Ong, 1991).

For Axelsson et al. (1994), the frequent and meticulous repetition of the oral health training is almost redundant. As it has been said a bove, a long-term favorable result will only be achieved with self-diagnosis and motivation for a change of behaviour (Axelsson et al., 1994; Albandar et al., 1994).

One should also be aw a re that the first individuals to change their behaviour will be the receptive ones, foll owed by the early adopters. It is on ly later that the tardy and do ubtful majority will incorpora te the idea, and the profe ssional should be prepared for those who will hardly adopt the philosophy of health prom otion and maintenance. In vi ew of this, it is important to consider that the purpose of mainten ance is to lead the individual to a change of beh aviour, with a gradual extension of his auton omy tow a rds self-ca re (Kri ger et al., 2003).

However, it must be considered that any ch ange in beh aviour demands time, and that it is essen tial to act on the whole group of individuals, for a positive answer will depend on a cultural change - consequently a gradual change - cen tered on the impact this kind of strategy will have on the population's health main ten a n cefrom then on (Kri ger et al., 2003).

\section{Discussion}

By virtue of the challenges posed in present times by the current health/sickness processes, Public Health has been re-thinking its performancebased on health prom otion aims, which attitude has contributed in a relevant way to the re-orientation of activities in this sector.

Thus, starting from the principle that oral health promotion consists of a ny planned effort to build public health policies and to cre- 
ate adequate environments, with sufficient su pport for improving the oral health of a given population (WHO, 1987), all the intervention stra tegies shift from the purely individual axis into the collective action. This demands the analysis of the population's living conditions in their several aspects: economical, social, environmental, and also inclu des the planning, programming and performance of the tasks to be implem ented in a program. The object of this program interven ti on does not consist only in risks and damages but chiefly the a gent that brin gs them abo ut, as well as the target populati on's health needs.

Confirming the statement above, and thus considering health as something greater than the absen ce of illness, it is sugge s ted that all the strategies defen ded in this article be coll ectively implemen ted, with the involvement of the whole community. However, in practice, this approach constitutes a great persistent challenge to public health, for the orchestration of the joint action of such divers entities as the government, civil society organizations, target populati on and health agents acting in the program can be considered extremely difficult to attain - especially when the duration of the program is taken into consideration.

In vi ew of the facts above, it is an intelligent at titu de to emphasize certain measu res that facilitate the process of oral health prom o tionand balance, with the aim of im proving the quality of lifein the target com munity. This holds true even wh en on ly part of the community becomes invo lved in the process, since some aspects repres ent fundamental points for the acquisition of healthy hygiene habits. They are edu cation, motiva tion and real commitment to the oral health in the target population (Ong, 1991) on the part of the professionals acting in the program. Furthermore, health education - one of the practices recommended by the authors - does not consist in telling people what is important to them, but in providing them with conditions in which they them selves can perceive the importance of health (Teixeira \& Valença, 1998). Health edu ca ti on should cease to be a process of in formation transfer and become a process for enabling both individuals and groups to transform reality (Rocha, 1989). It is from this perspective that dentist should work, steadfastly keeping to the purpose of transforming the pres ent oral health situ a ti on of the Brazilian pop ulation, even wh en faced with lack of support of s ome sectors of society.
According to Cabral (1998), there are weapons and strategies for fighting oral diseases, but the great ch allen gethe professional is confronted with is to motivate individuals to use this arsenal of knowledge conscious and correctly. And, even more important, not to all ow these health-pres erving habits to die of disuse.

Valla (1992) names praise and appreciation as motivational factors, but he warns that thoughthese resources are known to produ ce a very rapid ef fect, they nevert h eless last a regrettably short time. On the other hand, gre a ter responsibility or an increase in responsibility constitutes a motivational factor that produces both immed $i$ a te and long-term ef fects, which is why to en courage the individuals in a program to become responsible for their own oral health care is a frequ en tly used motivational recourse. However, du ring this process the victim should not be blamed for his disease; on the con trary, the populati on's health-illness situ a ti on should be related to their actual social condition.

Regular re-instruction and maintenance are crucial for the lon $\mathrm{g}$ - term su ccess of the programs (Guimarães et al., 1992). Actually, for the program to achieve favorable results, it is sugge sted that all the stra tegies propo sed in the pre sent study should be employed in tandem, even though the periodicity of each of them may be modifieddu ring the implem en tation of the program.

Still regarding planning, it is important to emphasize the role played by the sch ool within the con text of the program. The authors of the present study believe the school to be a venue of fundamental relevance for the su ccess of the program, for it is a place with a great concentration of children, who are an easy target for the acquisition of adequate habits. They are, th erefore, a population on wh $i$ ch the impact on oral health, fo stered by health promotion programs, seems to be more favorable. Furthermore, the school is the learning-conducive place par excellen ce, to which access is easy, and in which it is usually found both a great interest in and degree of acceptance of the proposed measu res on the part of the sch ool staff.

It becomes evident, in the light of the revision presen ted, that the health professional's role consti tutes the greatest strategy in the fight against such diseases at populational level. They should answer the oral health basic need s of society, and never take the complacent attitude of waiting for the global devel opm ent of the country to redu ce the high oral disease lev- 
els of the Brazilian population, such as caries and peri odontal disease.

Nevertheless, there remains a persistant question: Are health programs capable of implementing definitive and desirable oral hygiene habits, or do their ben efits lessen with the passing of time? (Heinfetz et al., 1973).

Julien (1994), as well as Ivanovic \& Lekic (1996), have observed that a prevention and oral health educational program improved the oral hygiene level of the target children, but only temporarily. It was verified that the reduction of bi ofilm and gingival inflammati on achieved during the program was dissipated after its conclusion. It is thus interesting to evaluate programs at certain intervals, after their ending, with the goal of verifying their long-term effect, for the actual duration of the ben efits brought about by the programs should be borne in mind and assessed by their organizers.

\section{Con tributors}

Antonio AG, Maia LC, Vianna RBC, Quintanilha LELP have con tributed in the same way to get the final vers $i$ on of the manuscript.

\section{References}

Albandar JM, Buishi YAP, Mavers MPA \& Axelsson P 1994. Long-Term Effect of Two Preven tive Programs on the Incidence of Plaque and Gingivitis in Adolescents. Journal of Periodontology 65(6):605-610.

Albandar JM, Buischi YAP, Oliveira LB \& Axelsson P 1995. $\mathrm{L}$ ack of ef fect of oral hygi ene training on peri odon $\mathrm{tal}$ disease progression over 3 ye a rs in adolescents. Journal of Periodontology 66(4):255-260.

Axelss on P, Buishi YAP, Ba rbosa MF, Karlsson R \& Prado MCB 1994. The ef fect of a new oral hygi ene training program on approximal caries in 12-15-year-old Brazilian child ren: re sults after threeye a rs. Adv Dent Res 8(2):278-284.

Axelss on P \& Lindhe J 1974. The effect of a preventive programme on dental plaque, gin givi tis and caries in schoolchildren. Re sults after one and two ye a rs. Jou $r$ nal of Clinical Periodontology 1(2):126-138.

Axelsson P, Paulander J, Svärdström G, Tollskog G \& Nordensten S 1993. Integrated caries prevention: effect of a needs-rel a ted preven tive program on dental caries in children. Caries Research 27(1):83-94.

Buischi YP \& Axelsson P 1997. Controle mecânico da placa dental realizada pelo paciente, pp.113-128. In L Kriger (org.). ABOPREV-Promoção de saúde Bucal, São Paulo: Editora Artes Médicas, São Paulo.
Cabral ICT 1998. Motivação: o grande desafio. Revista Fluminense de Saúde Coletiva 3(4):23-32.

Carvalho JC, Ekstrand KR \& Thylstrup A 1989. Dental plaque and caries on occlusal surfaces of first perma$\mathrm{n}$ ent molars in relation to stage of eru ption. Journal of Dental Research 68(5):773-779.

Carvalho JC, Ekstrand KR \& Thylstrup A 1991. Results after 1 year of non-operative occlusal caries treatment of erupting permanent first molars. Community Dental Oral Epidemiology 19(1):23-28.

Carvalho JC, Thylstrup A \& Ekstrand KR 1992. Results after 3 ye a rs of $n$ on - opera tive occlusal caries trea tment of erupting permanent first molars. Community Dental Oral Epidemiology 20(4):187-192.

Dawes C \& Jenkins GN 1962. Some inorganic constituents of dental plaque and their relationship to early calculus formation and caries. Arquive of Oral Biology 7:161-172.

Ekstrand KR, Kuzmina IN, Kuzmina E \& Christiansen MEC 2000. Two and a half-year outcome of cariespreventive programs of fered to groups of child ren in the Solnts evs ky Dis trict of Mos cow. Caries Re search 34(1):8-19.

Guimarães L, Mendes S, Pomarico I \& Portela W 1991/ 1992. Prevenção aplicada à clínica de od o n toped ia tria 
da FO-UFRJ: enfoque dieta e higiene oral. Anais da Faculdade de Odon tologia - UFRJ XLIV/XLV:13-19.

Hamada S \& Slade HD 1980. Biology, immunology, and cariogenicity of Streptoco ccus mutans. Microbiology Review 44(2):331-384.

Hei fetz SB, Bagramian RA, Suomi JD \& Segreto VA 1973. Programs for the mass con trol of plaque; an appraisal. Jou rnal of Pu blic Health Dentistry 33(2):91-95.

Hodge HC, Holloway PJ \& Bell CR 1982. Factors associated with toothbrushing behaviour in adolescents. British Dental Journal 152(2):49.

Ivan ovic M \& Lekic P 1996. Transient effect of a shortterm educational programme without prophylaxis on control of plaque and gingival inflammation in school children. Journal of Clinical Periodontology 23(8):750-757.

Julien MG 1994. The effect of behavior modification techniques on oral hygiene and gingival health of 10year-old Canadian child ren. In ternational Jou rnal of Paediatric Dentistry 4(1):3-11.

Kelstrup J \& Theil ade E 1974. Mi c robes and peri odontal disease. Jou rnal of Clinical Periodontology 1(1):15-35.

Kri ger L, Moysés SJ \& Dzierwa S 2003. A filosofia de promoção de saúde na clínica privada, pp. 443-462. In L Kriger (org.). ABOPREV - Promoção de saúde Bucal. Editora Artes Médicas, São Paulo.

Marthaler TM \& Moos B 1983. Observati on on gingival health in community with and wit th o ut school-based preven tive program. Journal of Clinical Periodontology 10(6):602-608.

Mastrantonio SDS \& Garcia PPNS 2002. Programas educativos em saúde bucal - Revisão da Literatura. Jornal Brasileiro de Odontopediatria e Odontologia para Bebê 5(25):215-222.

Mill er WD 1993. The microor ganisms of human mouth. Reprint 1973. Basel: S. Kar ger, 1890 a pud Asikainen S \& Alaluusua S. Bacteriology of dental infections. European Heart Journal 14(Suppl.K):43-50.

Minkovitz CS, O'Campo PJ, Chen YH \& Grason HA 2002. Associations between maternal and child health status and patterns of m edical care use. Ambulatory Pediatrics 2(2):85-92.

Ong G 1991. Practical Strategies for a Plaque-Con trol Program. Clinical Preven tive Dentistry 13(3):8-11.

Petry PC \& Pret to SM 2003. Educação e motivação em saúde bucal, pp. 371-386. In L Kriger (org.) . ABOPREV - Promoção de saúde bucal. Editora Artes Médicas, São Paulo.

Rayner JA 1992. A dental health education programme, including home visits, for nurs ery sch ool children. British Dental Journal 172(2):57-62.

Resende ALM 1986. Saúde dialética do pensar e do fazer. Cortez Editora, São Paulo.

Rocha CMV 1989. Educação em saúde: breve histórico e perspectivas. In Brasil. Mnistério da Sa ú de. Brasília, DF. Coletânea Educação, Saúde e Educação em Saúde.
Schwarz E, Lo ECM \& Wong MCM 1998. Prevention of early childhood caries - results of a fluoride toothpaste dem on stration trial on Chinese preschool chil$\mathrm{d}$ ren after three years. Journal of Public Health Dentistry 58(1):12-18.

Sgan-CohenHD \& Vered Y 2003. Plaque Rem oval and Oral Health Promotion Potential for the elm ex ${ }^{\circledR}$ interX Med ium Toothbrush: Clinical Efficacy and Sa fety Evaluation. Jou rnal Clinical of Den tis try 14(3):70-73.

Sheiham A 1977. Prevention and control of periodontal disease. International Co $n$ feren ce on Rese a rch in the Biology of Periodontal Disease. Un ivers ity of Illinois, Ch igago.

Sheiham A 1983. Promoting peri odontal health - effective programmes of educati on and promotion. In ternational Dental Journal 33(2):182-187.

Silveira JLGC, Oliveira V \& Padilha WWN 2002. Avaliação da redução do índice de placa visível e do índice de sangramen to gen gival em uma prá tica de promoção de saúde bucal com crianças. Pesquisa Odontológica Brasileira 16(2):169-174.

Slots J 1979. Subgingival microflora in peri odontal diseases. Jou rnal of Clinical Periodontology 6(5):351-382.

Teixeira MCB \& Valença AMG 1998. A importância da educação em saúde no ensino universitário: o caso da O dontologia. Revista Fluminense de Saúde Coletiva 2(3):7-33.

Tinanoff N 1995. Dental caries risk assessment and prevention. Dental Clinic of North American 39(4):709-719.

Valla VV 1992. Educação, saúde e cidad a nia: investigação científica e assessoria popular. Cadernos de Saúde Pública 8(1):30-40.

Weinstein P 1982. Humanisticapplication of beh avi oral strategies in oral higiene instruction. Clinical Preventive Dentistry 4(3):15-19.

Wentz FM 1972. Patient motivation: a new ch all en geto the dental profe s si on for ef fective con trol of plaque. Jou $r$ nal of American Dental Association 85(4):887-891.

WHO 1979. Principles and Meth ods of Health Education. Euro. Rep. Series 11.

Who 1987. Health Promotion, 1: iii-v.

Wilson TG 1987. Compliance. A review of the literatu re with possibleapplicati on to peri odontics. Jou rnal of Periodontology 58(10):706-714.

Zanata RL, Nava rro MF, Perei ra JC, Fra n coEB, Lauris JR $\&$ Ba rbosa SH 2003. Effect of caries preven tive measu res directed to ex pectant mothers on caries ex perience in their child ren. B razilian Dental Journal 14(2): 75-81.

Zickert I, Lindvall AM \& Axelsson P 1982. Effect on caries and gin givitis of a preven tive program based on oral hygi ene measu res and flu orideapplication. Co m munity Dental Oral Epidemiology 10(6):289-295.

Artigo apre s en tado em 23/08/2004

Aprovado em 22/06/2005

Versão final apresentada em 7/07/2005 